\title{
Money Supply, Deficit, and Inflation in Pakistan*
}

\author{
MOHAMMAD ASLAM CHAUDHARY and NAVED AHMAD
}

\section{INTRODUCTION}

Inflation is a burning issue in Pakistan. It is generally felt that for several years Pakistan has had a double-digit inflation. The public sector has used a mix of policies to control inflation, and it is also held responsible for its creation. The consumer price index (CPI) increased over 11 percent in 1981-82, and over 12 percent in 1990-91. Similarly, sensitive price index (SPI) increased over 15 percent in 1981-82, and over 12 percent in 1990-91. The GDP deflator was also double-digit for several years. Inflation not only affects sectoral allocation and distribution of income but also generates poverty. A prescription might not be appropriate until the roots of the disease are carefully investigated, which is the very reason for carrying out this study.

Studies by Hossain (1990) several others concluded that inflation is a monetary phenomenon in Pakistan, while Bilquees (1988) showed that structural factors explained the inflationary process in Pakistan. It is widely disagreed whether money supply is exogenous or endogenous. Vogel (1974), criticising the monetarist approach, argued that further research is needed on the determination of money supply. Given this background, this study is intended to identify the variables leading to inflation; the nature of money supply, endogenous or exogenous, is also analysed.

Section 2 of the study provides a brief review of the literature. A model is developed to study the relationship among fiscal deficit, money supply, and inflation. Section 3 contains a description of the empirical results. Section 4 provides the conclusion and policy implications.

\section{THEORETICAL BACKGROUND AND LITERATURE REVIEW (SUMMARY)}

The fiscal deficit in Pakistan has been alarming during the last two decades. The fiscal deficit was around 7.4 percent of the GDP during the period of 1970-80, and 7.6

Mohammad Aslam Chaudhary is Associate Professor at the Quaid-i-Azam University, Islamabad. Naved Ahmad is Lecturer at the University of Karachi.

"Due to the space limitations, only a summary of the main study is provided here. No detailed explanations are provided. 
percent during the 1980s. It was 8.5 percent in 1987-88 and around 7.9 percent in 199293. Inflation is considered to be an outcome of the same. Studies on the issue have been carried out by De Silva (1977), Aghevli (1977), Haan and Zelhorst (1990), and Chaudhary and Parai (1991) for the LDCs. A similar analysis was done by Hamburger and Zwick (1981), Protopapadakis and Siegal (1987), and Burnhart and Darrat (1988) for the developed countries.

Haan and Zelhorst (1990) analysed the relationship between government budget deficit and money growth in the developing countries. The overall conclusion of this study did not provide much support for the hypothesis that government budget deficit influences monetary expansion and, therefore, create inflation. Chaudhary and Parai (1991) have used a rational-expectations macro model of inflation to find out the effect of the anticipated budget deficit on inflation rates for Peruvian economy. They concluded that the country's huge budget deficit as well as high rates of growth of money did have a significant impact on the inflation rate. Similarly, there is much literature of disagreement on whether money supply is exogenous or endogenous. [Khan and Siddiqui (1990); Vogal (1974) and De Silva (1977)]. To study the above issues, the following model is utilised.

\section{The Model}

The model described here is based on the monetarist and quantity theory approach to inflation. Money supply equation may the form.

$$
\begin{aligned}
& \begin{array}{llllll}
M=f(T R, G B N B, C R) & \ldots & \ldots & \ldots & \ldots & \ldots
\end{array} \\
& \begin{array}{llllll}
T R=f(T R, B T, B F T) & \ldots & \ldots & \ldots & \ldots & \ldots
\end{array}
\end{aligned}
$$

We take the demand and supply equations in log form. The coefficient represents the respective elasticities. The demand for money is a function of income $(Y)$ and expected prices $(E P)$.

$\begin{array}{lllllll}M / P=f(Y, E P) & \ldots & \ldots & \ldots & \ldots & \ldots\end{array}$

The variables are defined as:

$T R=$ International Reserves or foreign assets.

$G B N B=$ Domestic financing of budget deficit including banking and nonbanking systems.

$C R=$ Commercial banks credit to the private sector. 
$E P$ is the proxy for the cost of holding real balance. Following Harberger, public adjust their expectation according to the following relationship.

$$
E P=\lambda\left(E P_{t}-E p_{t-1}\right) ; 0<\lambda<1 \quad \ldots \quad \ldots \quad \ldots
$$

The price equation is given as in the log forms which includes lagged money supply $(M)$, import price $(P M)$ and demand shift variable $(C S)$.

$$
\begin{aligned}
& \operatorname{In}(P)=c_{0}-c_{1} \operatorname{In}(Y)+c_{2} \operatorname{In}(E P)+c_{3} \operatorname{In}\left(M_{2}\right) \\
& +c_{4} \ln (P M)+c_{5} \ln (C S I) \quad \ldots \quad \ldots \quad \ldots \quad \ldots
\end{aligned}
$$

The output/income is a function of government expenditures (G. EXP), credit $(C R)$, real price of foreign exchange (RPFE), and exports $(X)$.

$$
\begin{aligned}
& \ln (Y)=d_{0}+d_{1} \operatorname{In}(G E X P)+d_{2} \operatorname{In}(C R)+ \\
& +d_{3} \operatorname{In}(R P F E)+d_{4} \operatorname{In}(X) \ldots \quad \ldots \quad \ldots \quad \ldots
\end{aligned}
$$

The balance-of-payment deficits is defined by exports, imports (IC), and capital payments (KT).

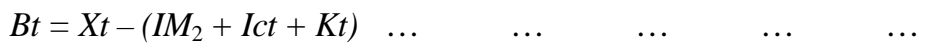

Finally, the supply of exports is a function of income $(Y)$, export price (PXP), and effective exchange rate (EER), as used by Aghevli (1977). It is also taken in the log form.

So the complete model becomes:

$$
\begin{aligned}
\operatorname{In}(M 2)= & a 0+a 1 \operatorname{In}(T R)+a_{2} \operatorname{In}(G B N B)+a_{3} \operatorname{In}(C R) \\
T R t= & T R t-1+b g+B t t \\
\operatorname{In}(M d / P)= & b 0+b 1 \operatorname{In}(Y)-b_{2} \operatorname{In}(E P t) \\
\operatorname{In}(P I)= & -c o-c_{1} \operatorname{In}(Y)+c_{2} \operatorname{In}(E P)+c_{3} \operatorname{In}\left(M 2_{-1}\right) \\
& +c_{4} \operatorname{In}(P M)+c_{4} \operatorname{In}(C S I) \\
\operatorname{In}(Y)= & d o+d 1 \operatorname{In}(G E X P)+d_{2} \operatorname{In}(C R)+d_{3} \operatorname{In}(R P F E) \\
& +d_{4} \operatorname{In}(X) \\
B t= & X t-(\operatorname{Im} 2+\operatorname{Ict}+K t) \\
\operatorname{In}(X)= & e 0+e l \operatorname{In}(Y)+e_{2} \operatorname{In}(P X P)+e_{3} \operatorname{In}(E E R)
\end{aligned}
$$


where:

$M d, M s, P I, Y, B t, T R$, and $X t$ are all endogenous, while $E P, G E N B, C R, G E X P$, $P X P, P M t, C S I, R P F E$ and EER are all exogenous variables, which have already been defined.

\section{EMPIRICAL ESTIMATION AND RESULTS}

We estimated the model using annual data for the periods 1973-92, 1973-82, and 1982-92. The basic model is simultaneous, which requires the use of 2SLS. However, we have used the OLS method because, according to De Silva (1977), the OLS method yields results roughly comparable to those obtained from the 2SLS method. The estimated results are shown in Tables 1, 2, and 3.

First we have estimated the given model for the whole time-period of 1973-92. The results are reported in Table 1. In Equation 1, the coefficients of GBNB, TR, and CR are all positive and significant at 1 percent level of significance. It indicates that a 10 percent increase in foreign reserves (TR) will increase each in money supply (M2) by 1.5 percent. GBNB will raise money supply by 1.51 percent, and commercial bank credit (CR) will increase the money supply by 6.4 percent. So around 64 percent change in money supply is triggered by commercial bank credit and 15 percent each by both domestic financing of budget deficits (GBNB) and international reserves (TR).

In Equation 2 (Table 1), the signs of coefficient are all expected and significant at 1 percent level of significance. As the level of income increases by 10 percent, it will raise demand for money by 11 percent, which means that there are dis-economies of scale in holding money, as usually happens in less developed economies because the income elasticity of the demand for money is greater than unity. The expected price level (as defined by Harberger) exerts negative pressure on real money demand.

Equation 3 is the price equation. Level of output (Y), lagged money supply (M21), and price of imports (PM) have expected sign and are significant. To check the monetary model while relaxing the assumption of the exogeneity of money supply, or to see the relationship between the monetary and the fiscal policies, we find that a 10 percent increase in lagged money supply and import prices will increase the price level by 4.8 percent and 5 percent, respectively.

In Equation 4, we have used the Cochran-Orcutt method to take care of autocorrelation. The sign of commercial credit (CR) is positive and significant at 1 percent level of significance. Its contribution is 20 percent to the level of output. The government expenditure (GEXP) played an important role in raising the economy's output. Furthermore, government expenditures are also a source of inflation because the government is forced to finance deficit resulting from non-commodity producing expenditure such as transfer payments, food subsidy, and the greater participation in social services. Since government expenditure has a significant impact on $\mathrm{Y}$, which 


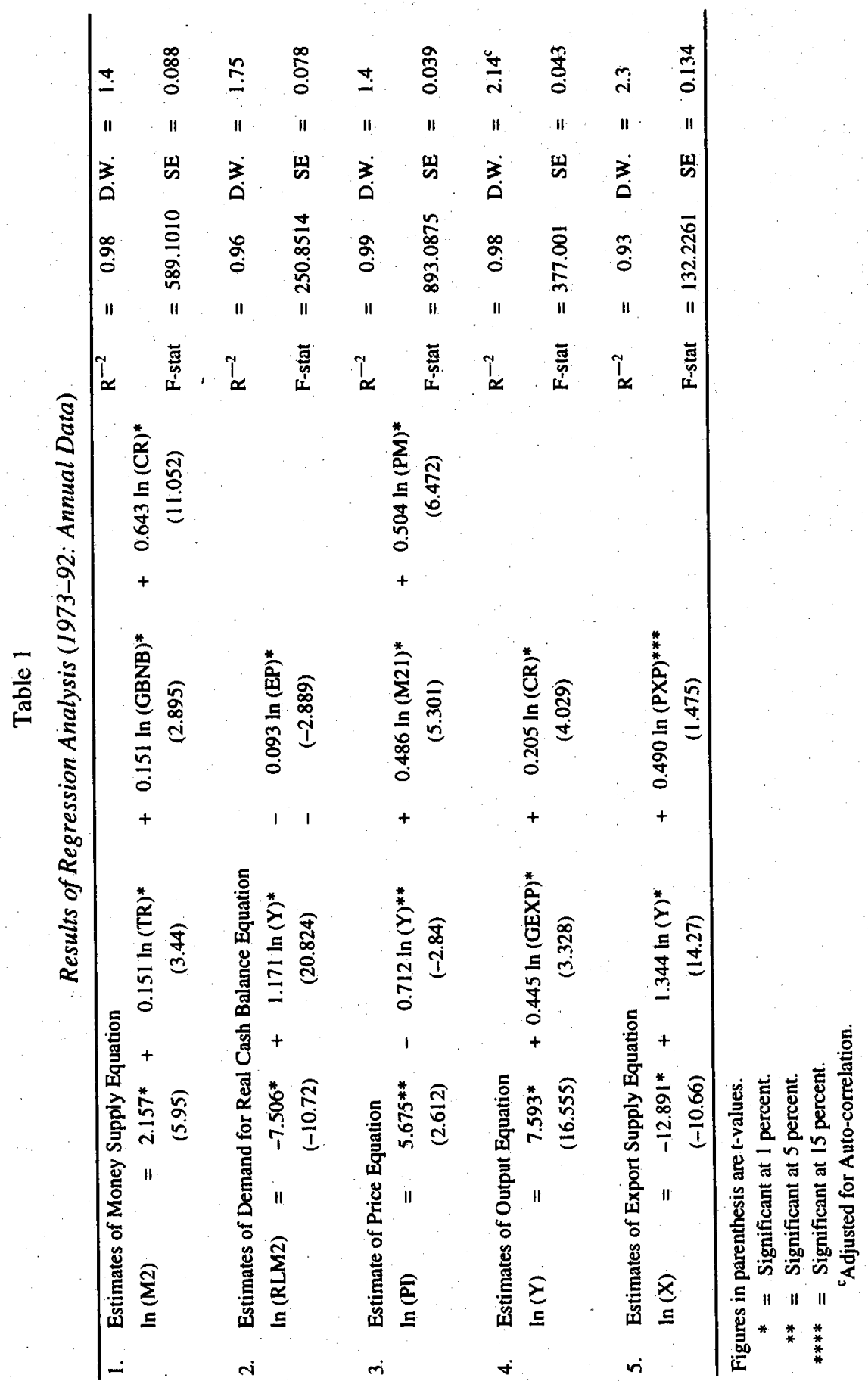




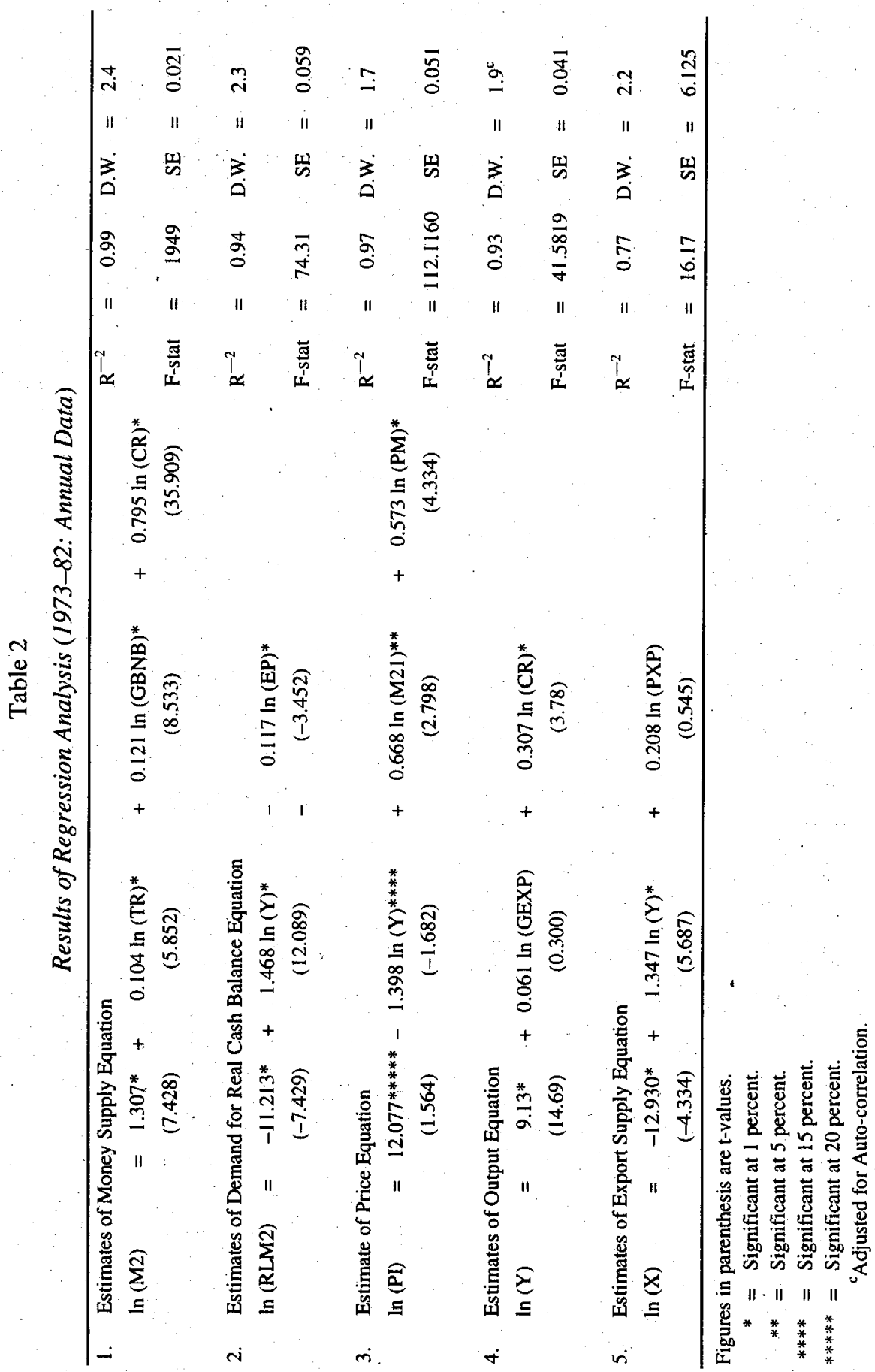




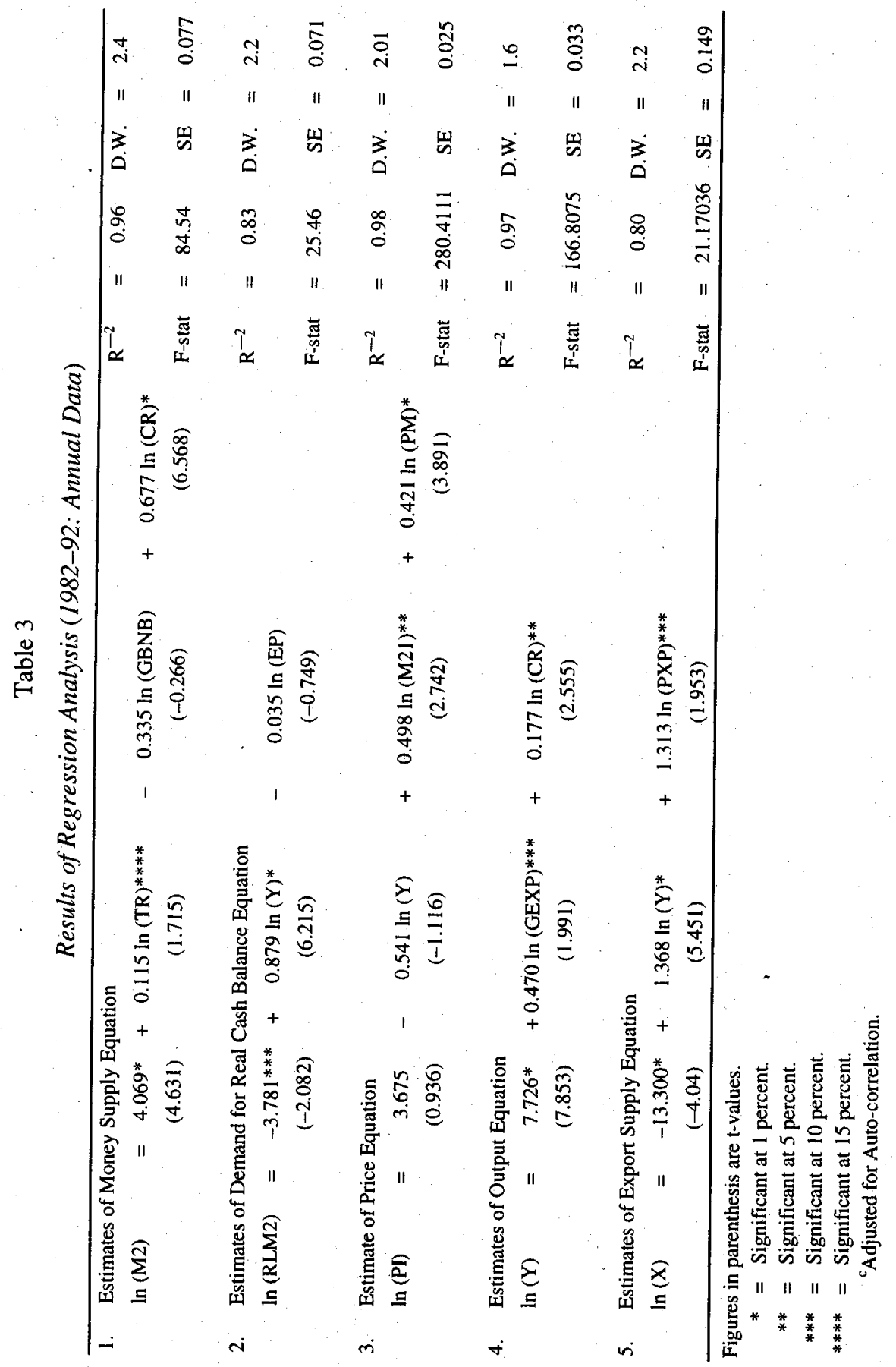


affects the demand for money, depending on the money market, this results in increasing the price level.

In our final Equation 5, all coefficients are significant. The positive sign of the coefficient of the ratio of unit value of exports to consumer price index shows that as consumer price index increases, it reduces the relative export prices, which, in turn, reduce the export. A 10 percent reduction in PXP will reduce the export by 4.9 percent. The sign of output coefficient could either be positive or negative depending on the income elasticity of domestic demand for exportable goods. If the domestic demand for exportables rises more than proportionally as income rises, coefficient of $\mathrm{Y}$ will be negative and fewer goods will be exported. Here our study found a positive relationship between output and exports.

The above discussion leads us to conclude that the financing of government budget deficits through domestic sources leads to increases in money supply and then the generation of inflation, which supports the accommodation hypothesis. The accommodation hypothesis does not merely state that budget deficit and money growth are positively correlated, but also that the higher budget deficits un-directionally cause higher money growth. Our finding - that long-run positive relationship between budget deficit and money supply or inflation exists - is consistent with the studies of De Silva (1977); Protopapadakis and Siegal (1987) and Haan and Zelhorst (1990).

The model was estimated for two different time-periods, i.e., for the 1970s and the 1980s. The results are reported in Table 2 and Table 3. The reason for this division of the time-period is that it is assumed that when there is a balance-of-payments deficit, the only remedy is to adjust the foreign reserves. This is only possible when we have a fixed exchange rate. Under flexible exchange rate, the market adjusts to the changes in the value of currency, which may correct the balance-of-payments deficit. Here our aim is to analyse the relationship between inflation and the exchange rate system. We intend to investigate the issue whether the fixed or the flexible exchange rate system is the more inflationary in nature.

During the decade of the 1970s, the coefficient of international reserve (TR) is positive (0.104) and significant (Table 2). Moreover, during 1980s, the effect of international reserve on money supply is higher (i.e., 0.115) and significant (Table 3). The reason was that during the flexible exchange rate system, government could depreciate the currency besides changing the foreign reserves to avoid a balance-ofpayments deficits. This depreciation would prevent a further decrease in foreign reserves. So the contribution of foreign reserves is larger. Besides, some deficits could be eliminated by taking advantage of the flexible exchange rate system.

So far as the inflationary pressure in the flexible exchange rate system is concerned, our findings showed that during 1980s the prior of fixed exchange rate, have exerted pressure on the price level than during 1970s. So here the flexible exchange rate system helped to overcome the inflationary pressure during the 1980s. It is noticed that 
during the flexible exchange rate system, a country is more open to accommodate inflation.

The contribution of PXP is less (0.208) during the 1970s than in the 1980s (1.3). It could be a result of the depreciation of the Pakistani Rupees, when the prices of exports were higher in the international market. Moreover, inflation is low during 1980s; so the relative price of exports (PX) increases, which, in turn, increases the exports, i.e., domestic export's become cheaper. This suggests that devaluation, despite supply rigidities, raises exports. The empirical results show that during the 1970s, the relationship between budget deficit, money supply, and inflation holds, but not during the 1980s. Our results suggest that there exists a positive relationship between deficits and inflation for the period of 1970s, when inflation was high. The relationship of deficit and money supply was not found significant for the 1980s, when the Government borrowed from non-bank sources. However, it might have led to crowding-out.

Our results pertaining to money supply indicated that the phenomenon may not be exogenous but may in fact be determined by TR, GBNB, and CR. With the changes in the sources of financing the budget deficit, the signs of GBNB also changed, showing the reversal impact on money supply. These findings are supported by Equation 1 (Tables 1, 2, and 3). It is an important contribution to the literature since, so far, it has always been assumed to be fixed and exogenous, which is not true, as per our findings.

\section{CONCLUSION AND POLICY IMPLICATIONS}

Our findings suggest that the domestic financing of budget deficit, particularly from the banking system, is inflationary in the long run. Our results provide support for a positive relationship between budget deficit and inflation during acute inflation periods, i.e., 1970s. We also find that money supply is not exogenous; rather it depends on the position of international reserves and fiscal deficit, and it has emerged as an endogenous variable.

The general conclusion emerging from all evidence discussed in this paper is that the execution of monetary policy may be determined by the central bank, but the overall formulation of policy is heavily dependent on the fiscal decisions made by the government. In order to control inflationary pressure, government needs to cut the size of budget deficit. It can perhaps be done by denationalising its numerous public sector activities, and also by cutting down drastically the size of its bureaucracy. Because there are many public utilities in which prices tend to be fixed, or at least are not allowed to change with inflation, a selfgenerating inflationary tendency occurs. The deficits arising in public sector need to be made up by government, which increases its own deficits. To finance this deficit, the money supply normally increases on action, which itself reinforces inflation. This suggests that government should take concrete and immediate steps to install a private business environment, limit its own size, and encourage, initiative in every sphere of economic life, if it is serious about controlling inflation. 


\section{REFERENCES}

Aghevli, B. B. (1977) Money, Prices and the Balance of Payment: Indonesia 1968-73. Journal of Development Studies 13: 2.

Barnhart, S. W., and A. F. Darrat (1988) Budget Deficits, Money Growth and Causality: Further OECD Evidence. Journal of International Money and Finance 7: 2.

Bilquees, F. (1988) Inflation in Pakistan: Empirical Evidence on the Monetarist and Structuralist Hypotheses. The Pakistan Development Review 27: 2.

Chaudhary, M. A. S., and A. K. Parai (1991). Budget Deficits and Inflation: The Peruvian Experience. Applied Economics 23.

De Silva, K. E. A. (1977) Money Supply, Inflation and the Balance of Payments in Sri Lanka 1959-74. The Journal of Development Studies 13: 2.

Haan, J. D., and D. Zelhorst (1990) The Impact of Government Deficits on Money Growth in Developing Countries. Journal of International Money and Finance 9: 4.

Hamburger, M. J., and B. Zwick (1982) Deficits, Money and Inflation, Reply. Journal of Monetary Economics 10:2.

Hossain, M. A. (1990) The Monetarist versus the Neo-Keynesian Views on the Acceleration of Inflation: Some Evidence from South Asian Countries (with special emphasis on Pakistan). The Pakistan Development Review 29: 1.

Khan, A. H., and A. N. Siddiqui (1990) Money, Prices and Economic Activity in Pakistan: A Test of Casual Relation. Pakistan Economic and Social Review 27:2.

Protopapadakis, A. A., and J. Siegal (1987) Are Money Growth and Inflation Related to Government Deficits? Evidence for Ten Industrialised Economies. Journal of International Money and Finance 6:1.

Vogel, R. C. (1974) The Dynamics of Inflation in Latin America 1950-60. Applied Economics Review 64: 1. 


\section{Comments}

In this study a simultaneous equation model has been discussed to analyse the relationship between money supply, budget deficit, and inflation. In this model, money supply, money demand, prices, output, and exports are determined endogenously. The model is similar to the model reported by the De Silva (1977), except for the price equation. The authors argue that deficit financing through increase in money supply is expected to generate inflation. The hypothesis, as suggested in this study, has been tested in a number of empirical studies in a simultaneous equation framework. However, the following aspects should be discussed more clearly in this paper.

(1) The authors report a simultaneous equation model but they do not estimate it simultaneously. The authors argue the Full Information Maximum Likelihood (FIML) estimation method can not be used as it is sensitive to specification errors. The authors could have used 2SLS instead of FIML. Another argument is De Silva's assertion that single equation estimation and simultaneous equation estimation give similar results. The authors should test whether this is true for Pakistan also.

(2) The authors are using De Silva's model specification. They could have improved the model by respecifying some equations. For example, domestic demand component could be explicitly included in the model. The budget deficit can be included in the price-level equation to examine the direct impact of budget deficit on prices. Similarly, the import demand function could be explicitly specified to examine the impact of the price of imports.

(3) The authors also examine whether the changes in exchange rate regimes (Fixed vs. Floating) affect the price level. For this purpose, they estimate each equation, for each period separately, i.e., for the 1972-82 period and for the 1982-92 period. I do not understand the rationale for separate equations for each subperiod when standard dummy variable techniques can help us to test the hypothesis without the loss of degrees of freedom. Furthermore, the application of dummy variable technique can enable us to examine whether the numerical differences in the coefficients are also statistically significant or not.

(4) The estimated equations should be discussed more clearly and carefully. This section on results needs clarifications at the following points: 
(a) Table 1 shows that all the variables have expected signs except for the output equation, where government expenditure and credit have a negative effect on output. What is the explanation?

(b) The authors interpret the coefficients as long-run estimates but, in fact, these are short-run estimates.

(c) The results for sub-period models show a positive effect of government expenditure and credit on output, but it is negative for the whole period. What is the justification and rationale?

(5) In order to examine the basic hypothesis of the paper, it would have been more appropriate to include higher order lagged values of the explanatory variables. Only then can we say whether budget deficit affects inflation or not, because it is the adjustment lag between government expenditure and government revenue which leads to inflationary financing of deficit. For example, De Silva (1977) and Bilquees (1988), both, show that a 3-year lag of price of imports has a statistically significant effect on the price level.

The authors also argue that the reason for the statistically insignificant relationship between money supply and deficit, during the 1980s, is the rising proportion of public debt. In that case, it may be more appropriate to include the public debt variable explicitly in the analysis.

Pakistan Institute of

Rehana Siddiqui

Development Economics,

Islamabad. 